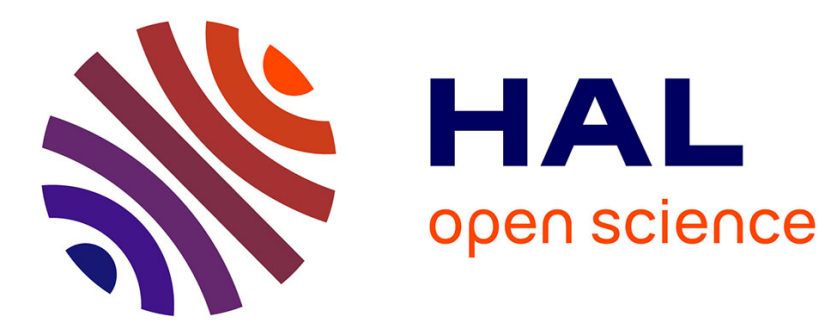

\title{
Energy management strategy for coupling supercapacitors and batteries with DC-DC converters for hybrid vehicle applications
}

Mamadou Baïlo Camara, Frédéric Gustin, Hasna Gualous, Alain Berthon

\section{To cite this version:}

Mamadou Baïlo Camara, Frédéric Gustin, Hasna Gualous, Alain Berthon. Energy management strategy for coupling supercapacitors and batteries with DC-DC converters for hybrid vehicle applications. 2008 13th International Power Electronics and Motion Control Conference (EPE/PEMC 2008), Sep 2008, Poznan, Poland. pp.1542-1547, 10.1109/epepemc.2008.4635486 . hal-02994935

\section{HAL Id: hal-02994935 \\ https://hal.science/hal-02994935}

Submitted on 8 Nov 2020

HAL is a multi-disciplinary open access archive for the deposit and dissemination of scientific research documents, whether they are published or not. The documents may come from teaching and research institutions in France or abroad, or from public or private research centers.
L'archive ouverte pluridisciplinaire HAL, est destinée au dépôt et à la diffusion de documents scientifiques de niveau recherche, publiés ou non, émanant des établissements d'enseignement et de recherche français ou étrangers, des laboratoires publics ou privés.

\section{(c)(1)}

Distributed under a Creative Commons Attribution| 4.0 International License 
See discussions, stats, and author profiles for this publication at: https://www.researchgate.net/publication/224331466

\section{Energy management strategy for Coupling Supercapacitors and Batteries with DC-DC converters for hybrid vehicle applications}

Conference Paper $\cdot$ October 2008

DOI: 10.1109/EPEPEMC.2008.4635486 · Source: IEEE Xplore

\section{CITATIONS}

16

4 authors, including:

\section{M.B. Camara}

Université du Havre

113 PUBLICATIONS 1,752 CITATIONS

SEE PROFILE

A. Berthon

University of Franche-Comté

78 PUBLICATIONS 1,902 CITATIONS

SEE PROFILE

Some of the authors of this publication are also working on these related projects:

Project These Intitul View project

Project breaking arc and renewable energy View project
135

Hamid Gualous

Université de Caen Normandie

244 PUBLICATIONS 4,010 CITATIONS

SEE PROFILE 
M.B Camara, F Gustin, H Gualous, A.Berthon, "Energy management strategy for Coupling Supercapacitors and Batteries with DC-DC converters for hybrid vehicle applications", $13^{\text {th }}$ IEEE Int. Power Electronics and Motion Control Conf. (EPE-PEMC 2008), 1-3 September 2008, Poland, Proceedings CD,pp.1565-1570, ISBN: 978-1-4244-1742-1 


\title{
Energy management strategy for Coupling Supercapacitors and Batteries with DC-DC converters for hybrid vehicle applications
}

\author{
M.B. Camara, F. Gustin, H. Gualous, $\underline{\text { A. Berthon }}$ \\ University of Franche-Comte, L2ES Laboratory \\ Rue Thierry Mieg Belfort, FRANCE \\ alain.berthon@univ-fcomte.fr \\ $\underline{\text { Tel. }+33384583604}$
}

\begin{abstract}
In this paper, the authors propose an approach to the problem of the energy management in ECCE laboratory project hybrid vehicle. ECCE is a series hybrid vehicle which currently has three sources of energy: two diesel motors each coupled with an alternator and a battery module of rated voltage DC $540 \mathrm{~V}$. This contribution is focused on the energy coupling between batteries and two supercapacitors modules. The authors present a strategy for coupling these power sources with the batteries in order to find the best compromise between sizes of the on-board devices, dynamics of the supply and efficiency of the energy storage. The target is to provide $200 \mathrm{~kW}$ power during $20 \mathrm{~s}$ from the supercapacitors modules.
\end{abstract}

Keywords-Hybrid electric vehicle (HEV), Supercapacitors, Energy storage, Energy converters for HEV, Energy system management, Hybrid power integration, Power converters for HEV

\section{INTRODUCTION}

Since nineties, the cars manufacturers reacted to the public interest regarding the urban pollution by commercializing the electric vehicles. But the obstacle of heavy, expensive battery and of insufficient capacity did not solve the problem. Indeed, the battery must be dimensioned to provide a sufficient energy, to reach the performances of the vehicle and the peak power during transient states. However the possibility of providing at the same time energy and an important power is currently a severe constraint, thus penalizing the batteries. To solve this problem, it is interesting to find other solutions for the implementation of an auxiliary power source to assist batteries during transient states. Among the various solutions of possible hybridization of the sources (batteries, supercapacitors, fly-wheels, fuel cell), the hybrid vehicle equipped with batteries and supercapacitors seems to be the promising solution in the short term. ECCE is a special HEV truck developed to test some new energy solutions. In this paper a short description of this 4 wheel drives truck will be provide. The full power rated of the system is about $160 \mathrm{~kW}$ provided mainly by two diesel engines. A 2tons pack of batteries will be connected to the DC common bus. In this paper the purpose is to study the connection between the batteries and a pack of supercapacitors which target will be to provide $200 \mathrm{~kW}$ during 20 s from a power peak request. SABER software is used for simulation and a data acquisition system with a microcontroller (PIC18F4431) is setup. The general topology of the hybrid system is presented in Fig1.

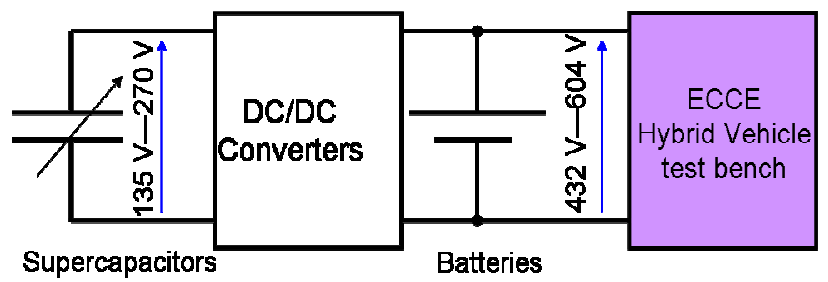

Fig1. General topology of hybrid system

\section{Boost CONVERTERs MODELING}

To associate the supercapacitors and batteries in ECCE hybrid vehicle DC-bus the parallel topology of the buckboost [1], [2], [3] has been proposed and this topology is presented in Fig.2.

This topology ensures the power management between the supercapacitors and battery [4], [5], [6], [7]. The supercapacitors modules are used during the hybrid vehicle transient states. The control strategy of these converters depends of the hybrid vehicle power request. To define the converters models the following assumptions are made:

- The semi conductors are ideal (no losses during switching and conduction states),

- No losses in the connecting devices

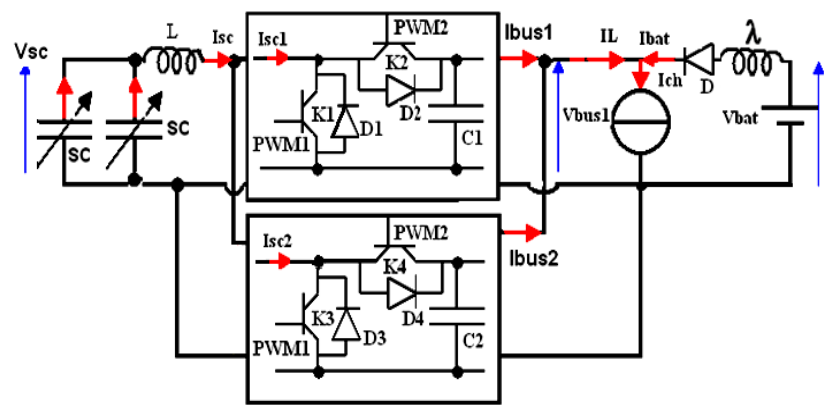

Fig.2: Parallel topology of the buck-boost converters 
By convention the flowing currents $\mathrm{I}_{\mathrm{sc} 1}, \mathrm{I}_{\mathrm{sc} 2}, \mathrm{I}_{\mathrm{L}}, \mathrm{I}_{\mathrm{bus} 1}$ and $\mathrm{I}_{\text {bus2 }}$ are positive during the supercapacitors discharge (boost converter mode). In this mode the PWM1 signals are ON and PWM2 signals are OFF. The supercapacitors module provides energy to the DC-bus [8], [9], [10]. The analytical model of the boost converter is given by equation (1); where $\alpha_{1}$ variable define the converter average duty cycle.

$$
\left\{\begin{array}{l}
V_{L}=L \cdot \frac{d}{d t}\left(i_{s c}\right)=V_{s c}-\left(1-\alpha_{1}\right) \cdot V_{b u s 1} \\
V_{s c}=V_{s c 1}=V_{s c 2} \\
V_{\lambda}=\lambda \cdot \frac{d}{d t}\left(i_{b a t}\right)=V_{b a t}-V_{b u s 1} \\
I_{c h}=I_{L}+I_{b a t}
\end{array}\right.
$$

The voltages drops in the $\mathrm{L}$ and $\lambda$ inductances are respectively given by $\mathrm{V}_{\mathrm{L}}$ and $\mathrm{V}_{\lambda}$. The converter average model has a nonlinear behavior because of crosses between the control variable $\left(\alpha_{1}\right)$ and the $\left(\mathrm{I}_{\mathrm{sc}}, \mathrm{V}_{\text {busl }}\right)$ state variables. The $\mathrm{V}_{\text {bus } 1}, \mathrm{~V}_{\mathrm{sc}}, \mathrm{I}_{\mathrm{ch}}$ and $\mathrm{V}_{\text {bat }}$ variables are likely to disturb the control; they must be measured and used in the estimate of the control law to ensure a dynamics of control.

\section{Converters Control Strategy}

The boost converters control strategy [11], [12] is presented in Fig. 3 and the used control law is defined by the boost converters average duty cycle (2).

$\alpha_{1}=1-\frac{V_{s c}-V_{L}}{V_{b a t}-V_{\lambda}} \approx 1-\frac{I_{L}}{I_{s c}}$

This control law is used to generate PWM1 signals. The supercapacitors reference current (3) are obtained from energy management between the supercapacitors modules and DC-bus, where $\eta_{3 \text { th }}$ and $\eta_{4 \text { th }}$ are the first and second boost converters theoretical efficiencies $(95 \%)$.

$$
I_{\text {scref }}=\frac{1}{2} \cdot\left(\frac{\eta_{3 t h}+\eta_{4 t h}}{\eta_{3 t h} \cdot \eta_{4 t h}}\right) \cdot \frac{V_{b u s 1}}{V_{s c}} \cdot\left(I_{c h}-I_{b a t r e f}\right)
$$

The $\mathrm{V}_{\text {bus } 1}, \mathrm{~V}_{\mathrm{sc}}, \mathrm{I}_{\mathrm{ch}}$, and $\mathrm{V}_{\text {bat }}$ variables are likely to disturb the control. They must be measured and used in the estimate of the control law to ensure a dynamics of control.

The control strategy used is to store all measurement errors samples of the supercapacitors and battery currents to estimate the voltage drops in $\mathrm{L}$ and $\lambda$ inductors.

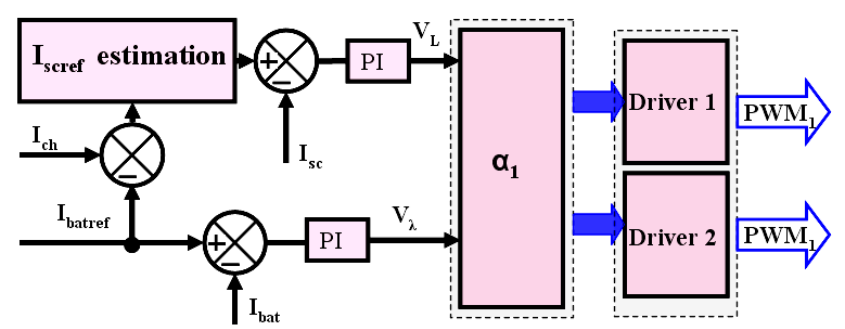

Fig. 3 : Boost converters control strategy
To make these estimations, it is necessary to provide to system the desired battery current reference $\left(\mathrm{I}_{\text {batref }}\right)$, the PI corrector's coefficients [11], the initial conditions of the $\mathrm{V}_{\mathrm{L}}$ and $\mathrm{V}_{\lambda}$.

\section{DESIGN AND EXPERIMENTAL SETUP}

For reasons of components cost and safety the experimental test bench was carried out at a reduced scale $(1 / 10)$. This test bench is made of:

- a batteries module of 4 cells in series,

- two supercapacitors modules of 10 cells (Maxwell-MC2600) in series for each one,

- $\quad$ an active load who is used to simulate hybrid vehicle power request,

- two buck-boost converters in parallel which ensure power management between the batteries and supercapacitors.

The supercapacitors modules voltages must be between $27 \mathrm{~V}$ and $13.5 \mathrm{~V}$. The batteries module which imposes the DC-bus voltage presents a rated voltage of $48 \mathrm{~V}$ and the DC-link voltage level must be between $43 \mathrm{~V}$ and $60 \mathrm{~V}$.

The control of the system is ensured by a Microchip's microcontroller (PIC18F4431) who presents 9 ADC input channels. The boost converters control frequency used is $10 \mathrm{kHz}$. The experimental parameters of the system and converter setup are respectively presented in TABLE I and Fig.4.

TABLE I

\begin{tabular}{|c|c|c|}
\hline Symbol & Value & Name \\
\hline $\mathrm{L}$ & $50 \mu \mathrm{H}$ & $\begin{array}{c}\mathrm{I}_{\mathrm{sc}} \text { smoothing } \\
\text { standard inductances }\end{array}$ \\
\hline $\mathrm{C}_{1}=\mathrm{C}_{2}$ & $1500 \mu \mathrm{F}$ & $\begin{array}{c}\mathrm{V}_{\text {bus1 }} \text { smoothing } \\
\text { standard capacitances }\end{array}$ \\
\hline$\lambda$ & $25 \mu \mathrm{H}$ & $\begin{array}{l}\mathrm{I}_{\text {bat }} \text { smoothing } \\
\text { inductance }\end{array}$ \\
\hline $\mathrm{V}_{\mathrm{sc}}$ & $13.5 \mathrm{~V}-27 \mathrm{~V}$ & $\begin{array}{l}\text { Supercapacitors } \\
\text { modules voltages }\end{array}$ \\
\hline $\mathrm{V}_{\text {bus1 }}$ & $43 \mathrm{~V}-60 \mathrm{~V}$ & DC-link voltage \\
\hline $\mathrm{T}_{\mathrm{e}}$ & $100 \mu \mathrm{s}$ & Sampling period \\
\hline
\end{tabular}

EXPERIMENTAL TEST BENCH PARAMETERS

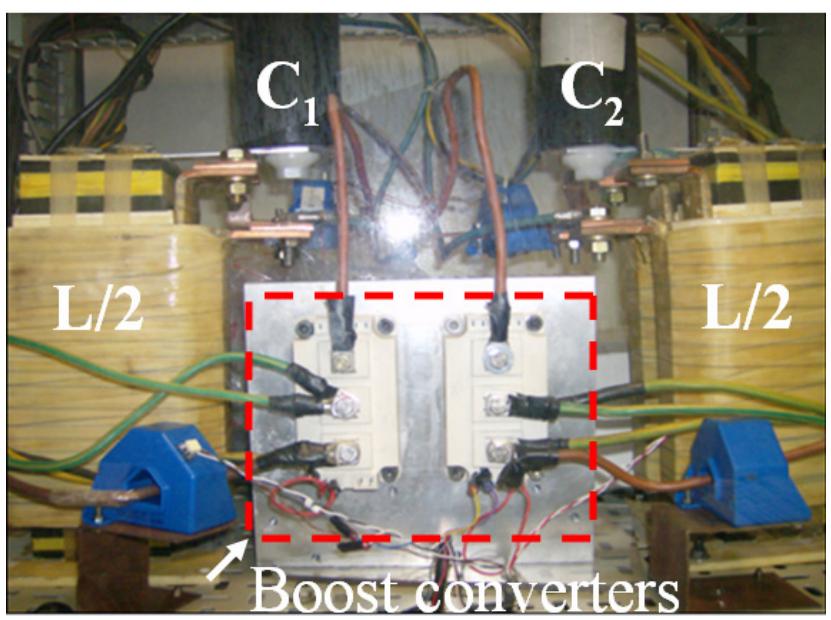

Fig.4: Experimental setup 


\section{Simulation AND EXPERIMENTAL RESUltS}

The boost converters experimental test is carried out in the following conditions: During the supercapacitors discharge, the batteries current reference $\left(\mathrm{I}_{\text {batref }}\right)$ is fixed at $14 \mathrm{~A}$ so that, the supercapacitors modules provide hybrid vehicle power request during the transient states. For these tests, the hybrid vehicle request $\left(\mathrm{I}_{\mathrm{ch}}\right)$ was fixed at 54A. The experimental and simulations results of the batteries current are compared in Fig.5. This figure shows the batteries current control strategy is satisfactory during $40 \mathrm{~s}$ after that it become insufficient because the supercapacitors discharge. In other words these curves show that the simulation model developed describes correctly the behavior of the experimental system during the first 40 seconds. After the first 40 seconds, the difference that appears between the experimental and simulation results explained by the fact one only supercapacitors module among the two parallel set has been characterized. This difference can be eliminated by adjusting the supercapacitors capacitance value or characterizing the two supercapacitors modules.

Fig.6 shows the supercapacitors experimental and simulations results during hybrid vehicle traction states. These results show the simulation model developed with SABER software is satisfactory for hybrid vehicle test bench behavior description.

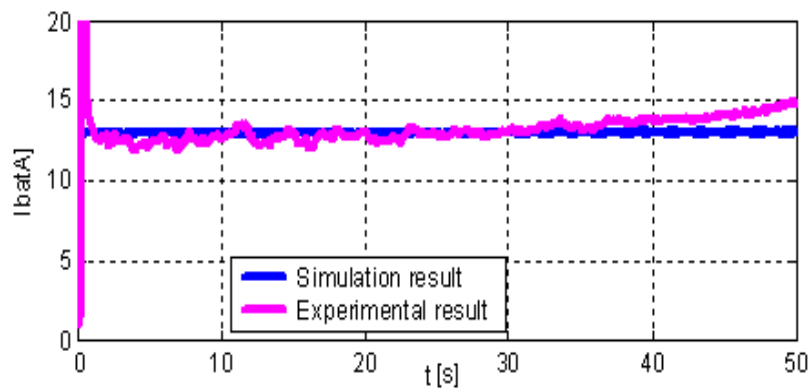

Fig.5: Battery current control results

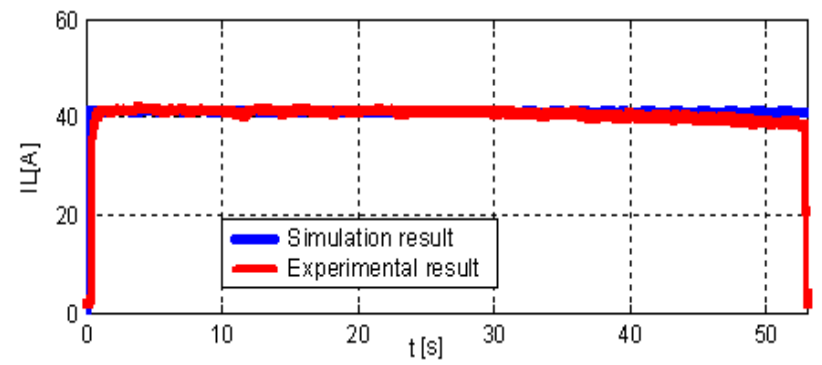

Fig. 7 : Hybrid vehicle DC-bus full current

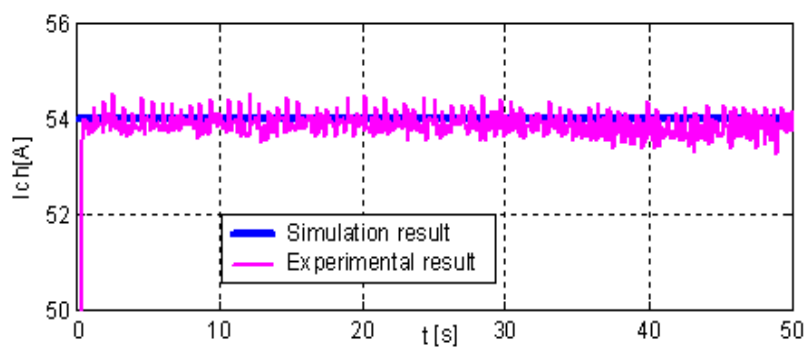

Fig.9: Hybrid vehicle request current
The DC-bus current $\left(\mathrm{I}_{\mathrm{L}}=40 \mathrm{~A}\right)$ presented in Fig.7 is ensure by two supercapacitors modules. The first boost converter (K1-D2) ensures $50 \%$ and the second (K3-D4) ensures also $50 \%$ of the DC-bus current. In other words the two super capacitors modules ensure a $\left(\mathrm{I}_{\mathrm{L}}\right)$ current of $40 \mathrm{~A}$ to hybrid vehicle and $14 \mathrm{~A}$ only is provided by the batteries.

Fig. 8 and Fig.10 show $\mathrm{I}_{\mathrm{sc} 1}$ and $\mathrm{I}_{\mathrm{sc} 2}$ currents are not same because the supercapacitors modules dispersion. The simulation and experimentation results of the hybrid vehicle request $\left(\mathrm{I}_{\mathrm{ch}}\right)$ current are well fitted and these results are presented in Fig.9.

Experimental and simulations results of the supercapacitors modules current and DC-bus voltage are respectively presented in Fig.11 and Fig.12. The first figure show the control strategy of the supercapacitors global current $\left(\mathrm{I}_{\mathrm{sc}}=\mathrm{I}_{\mathrm{sc} 1}+\mathrm{I}_{\mathrm{sc} 2}\right)$ is satisfactory during hybrid vehicle traction state.

The experimental tests is carried out with a classical battery module not entirely charged this is why appears a difference of $5 \mathrm{~V}$ approximately between the DC-bus voltage $\left(\mathrm{V}_{\text {bus } 1}\right)$ experimental and simulations results (Fig.12). This difference is also caused by the simulations model which is ideal (no losses).

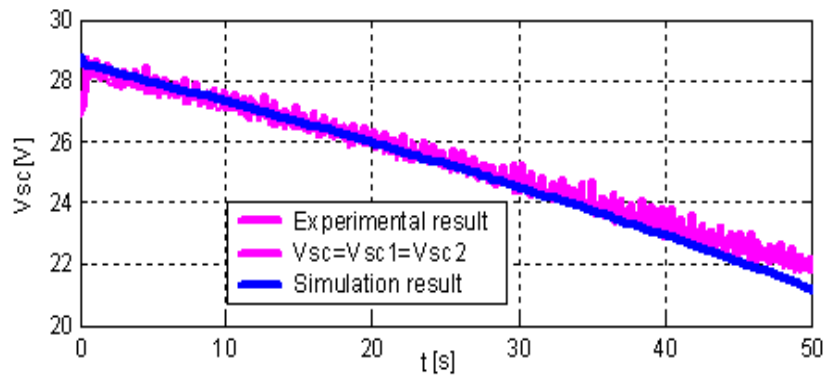

Fig.6: Two supercapacitors modules voltages

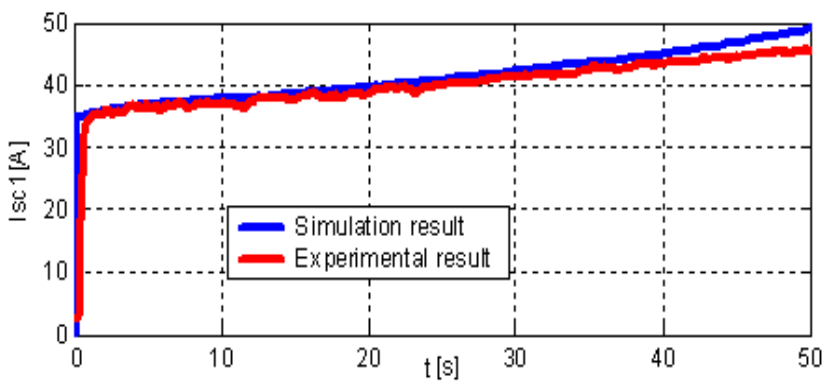

Fig.8: First supercapacitors module current

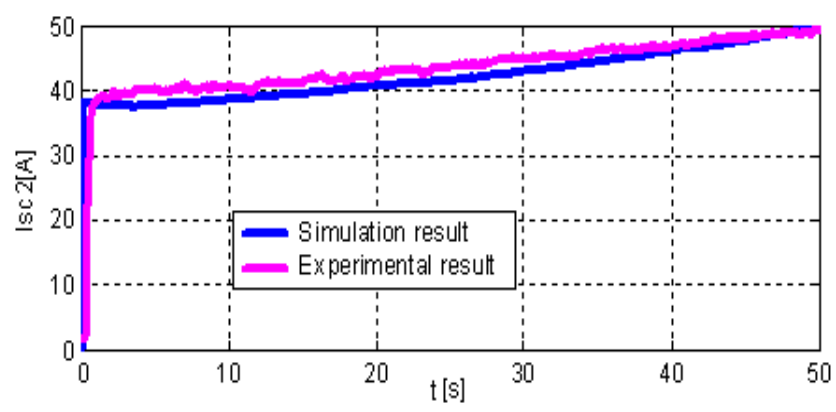

Fig.10: Second supercapacitors module current 


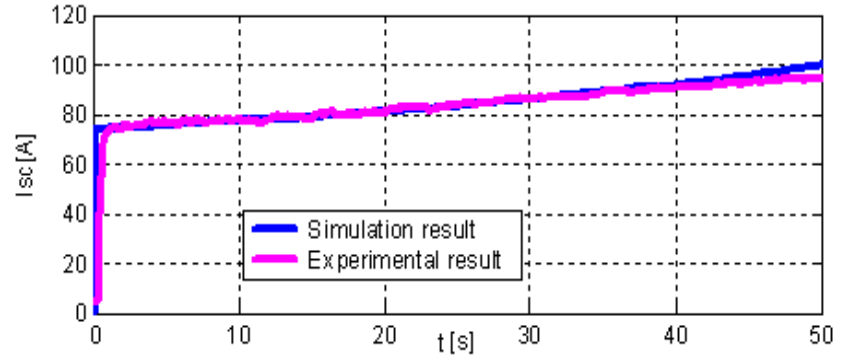

Fig.11: Supercapacitors modules full current

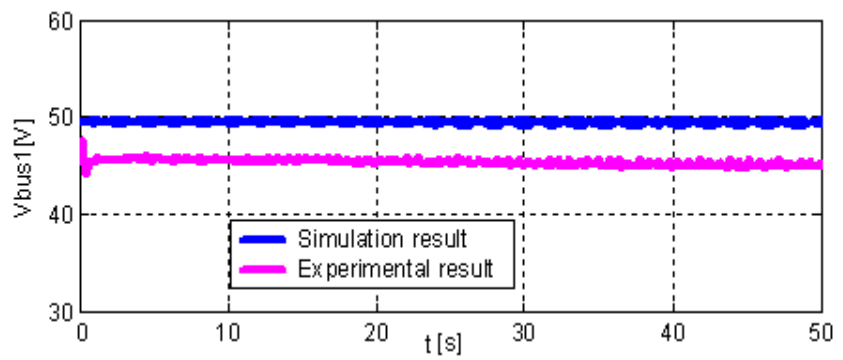

Fig.12: DC-bus voltage

\section{POWER SEMI-CONDUCTORS LOSSES ESTIMATION}

The power semi-conductors (IGBT) present two main types of losses [13]. The first losses are due to semiconductors dynamics resistances (internal) and second are due to IGBT frequency switching [14] witch are not studied in this paper. To illustrate and simplify the IGBT and Diodes conduction losses estimation the voltage drops in these components has been considered constant. The power semi-conductors (SKM400GB124D) parameters extracts in manufacturer datasheet are summarized in TABLE.II

To estimate the semiconductors losses, it is necessary to know the DC/DC converters (boost) duty cycle average value which is defined by (4).

$d_{1}=d_{2}=\frac{V_{b u s 1}-V_{s c}}{V_{b u s 1}}$

TABLE II

POWER SEMI-CONDUCTORS PARAMETERS

\begin{tabular}{|c|c|c|}
\hline Symbol & Value & Name \\
\hline $\mathrm{V}_{\mathrm{CE}(\mathrm{T} 0)}$ & $1.25 \mathrm{~V}$ & $\begin{array}{l}\text { IGBT threshold } \\
\text { voltage }\end{array}$ \\
\hline $\mathrm{R}_{\mathrm{CE}}$ & $5.3 \mathrm{~m} \Omega$ & $\begin{array}{c}\text { Dynamic resistance } \\
\text { of IGBT }\end{array}$ \\
\hline $\mathrm{V}_{(\mathrm{T} 0)}$ & $1.2 \mathrm{~V}$ & $\begin{array}{l}\text { Diodes threshold } \\
\text { voltage }\end{array}$ \\
\hline $\mathrm{R}_{\mathrm{T}}$ & $3.5 \mathrm{~m} \Omega$ & $\begin{array}{l}\text { Diodes dynamic } \\
\text { resistance }\end{array}$ \\
\hline$\Delta \mathrm{I}_{\mathrm{SC} 1}$ & $10 \% \mathrm{I}_{\mathrm{SC} 1}$ & $\begin{array}{c}\mathrm{I}_{\mathrm{SC} 1} \text { variation } \\
\text { current }\end{array}$ \\
\hline$\Delta \mathrm{I}_{\mathrm{SC} 2}$ & $10 \% \mathrm{I}_{\mathrm{SC} 2}$ & $\begin{array}{l}\mathrm{I}_{\mathrm{SC} 2} \text { variation } \\
\text { current }\end{array}$ \\
\hline$\left\langle\mathrm{I}_{\mathrm{sc1}}\right\rangle,\left\langle\mathrm{I}_{\mathrm{sc} 2}\right\rangle$ & $\mathrm{I}_{\mathrm{SC} 1}, \mathrm{I}_{\mathrm{SC} 2}$ & $\begin{array}{r}\mathrm{I}_{\mathrm{SC} 1} \text { and } \mathrm{I}_{\mathrm{SC} 2} \\
\text { average values }\end{array}$ \\
\hline
\end{tabular}

The conduction losses of the D2 and D4 diodes can be estimated by using equation (5).

$$
\begin{aligned}
& \left\{\begin{array}{l}
P_{D 2}=\left(1-d_{1}\right) \cdot\left\langle I_{s c 1}\right\rangle \cdot V_{(T 0)}+R_{T} \cdot I_{D 2 \text { eff }}^{2} \\
P_{D 4}=\left(1-d_{2}\right) \cdot\left\langle I_{s c 2}\right\rangle \cdot V_{(T 0)}+R_{T} \cdot I_{D 4 e f f}^{2}
\end{array}\right. \\
& \left\{\begin{array}{l}
I_{D 2 \text { eff }}^{2}=\left(1-d_{1}\right) \cdot\left(1+\frac{1}{12} \cdot\left(\frac{\Delta I_{s c 1}}{\left\langle I_{s c 1}\right\rangle}\right)^{2}\right) \cdot\left\langle I_{s c 1}\right\rangle^{2} \\
I_{D 4 \text { eff }}^{2}=\left(1-d_{2}\right) \cdot\left(1+\frac{1}{12} \cdot\left(\frac{\Delta I_{s c 2}}{\left\langle I_{s c 2}\right\rangle}\right)^{2}\right) \cdot\left\langle I_{s c 2}\right\rangle^{2}
\end{array}\right.
\end{aligned}
$$

For K1 and K3 semi-conductors (IGBT) conduction losses, they can be estimated by using (6).

$$
\begin{aligned}
& \left\{\begin{array}{l}
P_{K 1}=d_{1} \cdot\left\langle I_{s c 1}\right\rangle \cdot V_{C E(T 0)}+R_{C E} \cdot I_{K 1 \text { eff }}^{2} \\
P_{K 3}=d_{2} \cdot\left\langle I_{s c 2}\right\rangle \cdot V_{C E(T 0)}+R_{C E} \cdot I_{K 3 e f f}^{2}
\end{array}\right. \\
& \left\{\begin{array}{l}
I_{K 1 \text { eff }}^{2}=d_{1} \cdot\left(1+\frac{1}{12} \cdot\left(\frac{\Delta I_{s c 1}}{\left\langle I_{s c 1}\right\rangle}\right)^{2}\right) \cdot\left\langle I_{s c 1}\right\rangle^{2} \\
I_{K 3 e f f}^{2}=d_{2} \cdot\left(1+\frac{1}{12} \cdot\left(\frac{\Delta I_{s c 2}}{\left\langle I_{s c 2}\right\rangle}\right)^{2}\right) \cdot\left\langle I_{s c 2}\right\rangle^{2}
\end{array}\right.
\end{aligned}
$$

The $\mathrm{V}_{(\mathrm{T} 0)}, \mathrm{V}_{\mathrm{CE}(\mathrm{T} 0)}, \mathrm{R}_{\mathrm{CE}}$ and $\mathrm{R}_{\mathrm{T}}$ parameters present respectively the diode threshold voltage, IGBT threshold voltage, IGBT internal resistance and the diode resistance.

By using these equations the experimental results of $\mathrm{K} 1$ and D2 semi-conductors conduction losses for first boost converter is show in Fig.13 and that of second boost converter $(\mathrm{K} 3, \mathrm{D} 4)$ is presented in Fig. 14. The $\mathrm{P}_{\mathrm{K} 1}$ and $\mathrm{P}_{\mathrm{K} 3}$ values increases when the supercapacitors modules voltages decreases.

The boost converter efficiency [15], [16] is defined by the ratio between the DC-bus power and that of supercapacitors (7).

This efficiency depends to supercapacitors current. The progressive discharge of the supercapacitors modules is compensated by supercapacitors current progressive increase; which ensures increase the semi-conductors losses.

$$
n_{t_{-} P I}=\frac{\left(I_{b u s 1}+I_{b u s 1}\right) \cdot V_{b u s 1}}{\left(I_{s c 1}+I_{s c 2}\right) \cdot V_{s c}}
$$

The boost converters experimental efficiency resulting to this equation is presented in Fig. 15. This figure shows for $I_{s c}=76 \mathrm{~A}$ the converters efficiency is maximum $(87.5 \%)$. However, it is possible to improve this efficiency by optimising the wiring and using low losses power semiconductors (IGB, diode). 


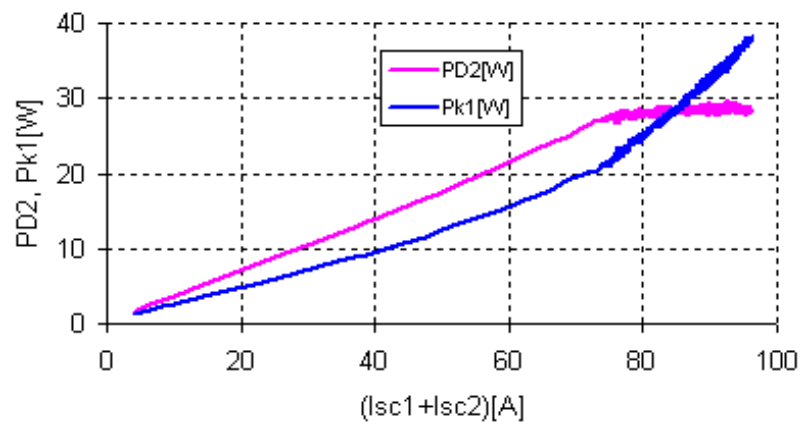

Fig.13: Losses of the first boost converter

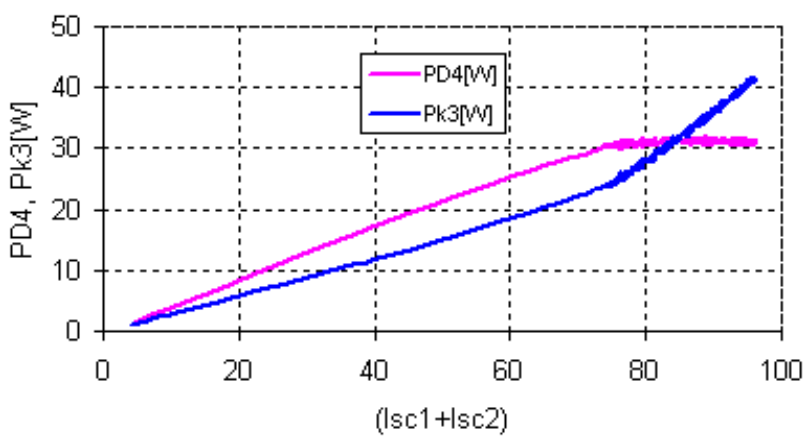

Fig.14: Losses of the second boost converter

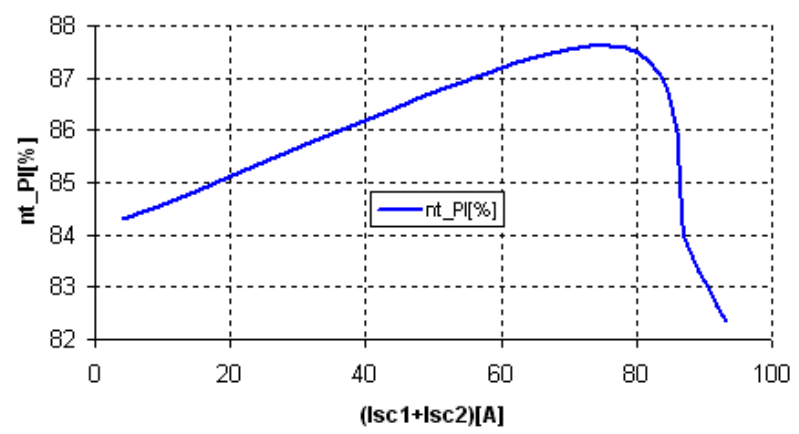

Fig.15. DC/DC converter efficiency

\section{CONCLUSION}

This paper presents a possibility of coupling the battery module and the supercapacitors in the ECCE hybrid vehicle DC-bus by using the parallel topology of the buckboost converters. This topology enables to decrease the supercapacitors current smoothing inductances number.

In this paper, the authors present the boost converter modeling and the original control strategy to share energy between the supercapacitors and batteries. To control the whole system, the boost converter law control is established. The supercapacitors reference current is calculated by the strategy of energy management in the hybrid vehicle. The resulting algorithm is very robust and simple to realize with a microcontroller or DSP components.

For reasons of cost and safety, the experimental test bench is carried out in reduced scale of $(1 / 10)$. The simulations and experimental results in reduced scale are compared. The battery current follows the reference value except when the supercapacitors modules voltages exceed the minimum voltage.

\section{ACKNOWLEDGMENT}

This work is under the continuity of the work started in L2ES Laboratory within the program framework ECCE in collaboration with Electronic and Electrical engineering Research Center of BELFORT (CREEBEL).

\section{REFERENCES}

[1] L.Solero, L. Lidozzi, J-A. Pomilio, Design of Multiple-Input Power converter for Hybrid Vehicles, IEEE Trans. On power Electronics, vol:20, No5, September 2005

[2] Camara M.B, Gustin F, Gualous H, Berthon A., "Studies and realization of the buck-boost and full bridge converters with multi sources system for the hybrid vehicle applications", Second European Symposium on Supercapacitors and Applications, ESSCAP2006, 2-3 November 2006, Lausanne, Switzerland, Proceedings CD

[3] Camara, M.B.; Gualous, H.; Gustin, F.; Berthon, A.; "Control strategy of Hybrid sources for Transport applications using Supercapacitors and batteries", Power Electronics and Motion Control Conference, 2006. IPEMC'06. CES/IEEE 5th International, Volume 1, Aug. 2006, Pages: 1-5

[4] Camara M.B, Gustin F, Gualous H, Berthon A., "Supercapacitors and Batteries powers management for Hybrid Vehicles Applications/ Using multi boost and multi full bridge converters", 12th European Conference on Power Electronics and Applications EPE 2007, ISBN: 9789075815108, 2-5 September 2007, Denmark, Proceedings CD

[5] Camara, M.B.; Gualous, H.; Gustin, F.; Berthon, A.; "Experimental study of Buck-Boost converters with polynomial Control strategy for Hybrid Vehicles Applications", International Review of Electrical Engineering (IREE), ISSN 1827-6660,Vol.2, No.4, Pages:601-611, July-August 2007

[6] B. Michael, B.Burnett, L.J. Borle, A power system combining batteries and supercapacitors in a solar/hydrogen hybrid electric vehicle, IEEE,vol:3, Sept. 2005

[7] M. Marchesoni, C. Vacca, A New DC-DC Converter Structure for Power Flow Management in Fuel-Cell Electric Vehicles with Energy Storage Systems, 2004 35thAnnual IEEE Conf. Power Electronics Specialists, Germany

[8] P.Thounthong,S.Raël,B.Davat, Control strategy of fuel cell/supercapacitors hybrid power sources for electric vehicle, Journal of Power Sources September 2005

[9] P. Mestre, S.Astier, Utilization of Ultracapacitors as auxiliary power source in Electric Vehicle, EPE ,vol:4, pp4670-4673, Sept.1997

[10] A. Di Napoli, F.Crescimbini, L. Solero, F. Caricchi, F.G. Capponi, Multiple-Input DC-DC power for power-flow management in hybrid vehicles, IEEE,vol.3,pp1578-1585,oct 2002

[11] Camara M.B., Gualous H., Gustin F. and Berthon A., "Design and New Control of DC/DC Converters to share energy between Supercapacitors and Batteries in Hybrid Vehicle", IEEE Transactions on Vehicular Technology (in press)

[12] Wenxun Xiao, Bo Zhang, Dongyuan Qiu, "Analysis and Design of an Automatic-Current Sharing Control Based on Average-Current Mode for Parallel Boost Converters", IPEMC2006, vol.2,pp1-5

[13] Carlos A. Canesin, and Ivo Barbi, "Comparaison of experimental losses among six different topologies for a $1.6 \mathrm{~kW}$ Boost converter, Using IGBT'S",IEEE, PESC1995, vol.2,pp1265-1271

[14] Scott Castagno, Randy D. Curry, and Ellis Loree "Analysis and Comparaison of a Fast Turn-On Series IGBT Stack and HighVoltage-Rated Commercial IGBTS", IEEE Trans. On plasma science, vol.34,No.5, pp1692-1696

[15] Hein van der Broeck, Ibrahim Tezcan, "1KW Dual Interleaved Boost Converter for Low Voltage Applications", IPEMC2006, vol.3,pp1-5

[16] Dong Li, and Xinbo Ruan "A High Efficiency Boost Converter With Power Fractor Correction",IEEE Power Electronics Specialists Conference, 2004, vol.2, pp1653-1657 


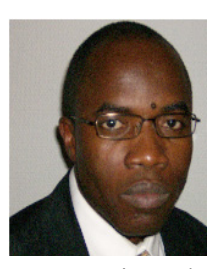

Dr. Mamadou Baïlo Camara was born in Mamou, Guinea. He got his engineer degree from Polytechnic Institute of Conakry (IPC), Guinea in 2003, and the Master degree in 2004 from the University of Franche-Comté, France, where he received his Ph.D degree in 2007. Since 2004, he has been working in power electronics and electric vehicle research projects, involving static converter topologies, supercapacitors, batteries, and electrical power management for Hybrid Vehicle Applications.

Dr. Frederic Gustin received his Ph.D. degree in 2000 from the University of Franche-Comté, Belfort France. His research activities involve power electronics, converters and simulation methods at the L2ES laboratory. $\mathrm{He}$ is presently associate Professor at the I.U.T (Institute of technology) of Belfort, France.

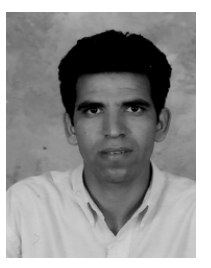

Dr. Hamid Gualous was born in Morocco on January 1967,. He received his Ph.D in electronic from the University Paris XI Orsay, France, in 1994. Since 1996, he is Associate Professor at the University of Franche-Comté France, L2ES laboratory. His main research activities are concerning supercapacitor and fuel cell dedicated to transport applications, power electronics and energy management.

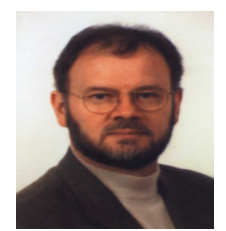

Pr. Alain Berthon, received his Dipl. engineer in electrical engineering from ENSEM in Nancy in 1972 and his Dr. Ing. degree from the University of Franche-Comté. He is currently Professor at IUT and head of power electronics team at the L2ES laboratory. He is working in the field of power electronics converters, drives and electrical power management for electrical vehicle. 